\title{
A hitherto unreported impurity in Terazosin - elucidation of the structure, synthesis and cytotoxicity
}

\author{
Benjamin Brandes ${ }^{1}$, Sophie Hoenke ${ }^{1}$, Hans-Peter Deigner ${ }^{2}$ and René Csuk $^{1, *}$ \\ ${ }^{1}$ Full Address: Martin-Luther-University Halle-Wittenberg, Kurt-Mothes- Str. 2, D-06120 Halle (Saale) \\ ${ }^{2}$ Full Address: Furtwangen University, Medical and Life Sciences Faculty, Jakob-Kienzle Str. 17, D-78054 \\ Villingen-Schwenningen, Germany
}

\begin{abstract}
Analysis of several batches of the $\alpha_{1}$-adrenergic blocking agent terazosin being used as a medication for treating benign prostatic hyperplasia and hypertension revealed the presence of a hitherto not reported impurity. The latter was isolated, and its structure was elucidated from NMR and Mass Spectrometry (MS) data and unambiguously confirmed by independent synthesis. This contamination, represented in 1-[4-(amino-6,7dimethoxyquinazolin-2-yl)-piperazin-1-yl]-pentane-1,2-dione 2 is likely to occur as the product of a side-reaction in the catalytic hydrogenation step during the synthesis of the drug. Biological screening showed this compound as not cytotoxic for several human tumor cell lines and non-malignant fibroblasts.
\end{abstract}

Keywords: Terazosin; reductive ring-opening; cytotoxicity; SRB assay.

\section{Introduction}

Drugs are developed, produced and marketed to be used as medications. They have to be delivered in utmost pure form. Their purification, however, is most often very challenging since there is an increased regulatory focus on impurities. A usual and generally accepted identification threshold is $0.1 \%$ for drugs whose maximum daily dose is less than or equal to $2.0 \mathrm{~g}$ while for those drugs whose daily dose exceeds $2.0 \mathrm{~g}$ the identification threshold is $0.05 \%{ }^{1-4}$. During a project dealing with the synthesis of postsynaptic<smiles>COc1cc2nc(N3CCN(C(=O)C4CCCO4)CC3)nc(N)c2cc1OC</smiles>

$\alpha_{1}$-adrenergic blocking agents, we came across the drug terazosin 1 (Fig. 1) ${ }^{5-9}$.

Terazosin was first used in medical practice in 1987 to treat benign prostatic hyperplasia ${ }^{10-12}$. A quarter of all 40-year-old men already have benign prostate hyperplasia with the number for 80-year-old men being above $80 \%$. While in stage 1 , a conservative "strategy of controlled waiting" is often supported by over-the-counter phytopharmaceuticals, but in stage 2 more effective drugs have to be used, such as $\alpha_{1}$ receptor blockers including Terazosin.

Figure 1. Structure of terazosin 1 and the hitherto unknown impurity $\mathbf{2}$

A second indication for Terazosin, although less widespread, is the treatment of hypertension. It is estimated that about $25 \%$ of the world's population has a too high blood pressure; by 2025 this number of patients is expected to rise to $29 \%$, which means that about 1.5 billion people will be affected ${ }^{13}$.
Recently, two other possible applications of Terazosin have become known. These include the treatment of hyperhidrosis (phase 4, NCT00449683) ${ }^{14-16}$ and a study indicating possible re-purposing of $\mathbf{1}$ to treat Parkinson's disease (PD) ${ }^{8}$. PD is the second most common neurodegenerative disease being first 
diagnosed in 1817 by the English physician James Parkinson. Nowadays, the number of patients worldwide has increased from 2.5 million in 1990 to 6.1 million in 2016. In 2016 alone, 3.2 million DALYs (disability-adjusted life years) - i.e. symptom-free years with a good quality of life - were lost worldwide due to this disease ${ }^{17}$. The disease recently claimed 200000 deaths per year. Recently, 1 has been repurposed 18,19 as anti-apoptotic drug targeting the human enzyme phosphoglycerate kinase 1 .

\section{Results and discussion}

These data indicate that there may be an increased need for Terazosin in the future. Given the recent problem of critical impurities in several drugs, we examined some batches of Terazosin for impurities. It became apparent that individual batches contained traces $(0.05-0.11 \%)$ of an impurity 2 not previously having been described in the literature. The structure of 2 was elucidated by the commercially obtained drugs which were extracted with methanol, and the extract was subjected to a repeated semi-preparative HPLC separation ( $\left.\mathrm{RP} 18, \mathrm{CH}_{3} \mathrm{CN} / \mathrm{H}_{2} \mathrm{O}\right)$ to yield pure 2 being subject to an excellent elucidation of its structure by Mass spectrometry and NMR spectroscopy. Low-resolution ESI MS showed a quasi-molecular ion $[\mathrm{M}+\mathrm{H}]^{+} \mathrm{m} / \mathrm{z} 388.27$; this finding was supported by HRMS showing m/z 388.1977 and
- as a consequence - a molecular formula of $\mathrm{C}_{19} \mathrm{H}_{26} \mathrm{O}_{4} \mathrm{~N}_{5}$. An ESI-MS fragmentation experiment gave fragments $\mathrm{m} / \mathrm{z} 360.2(\Delta \mathrm{m}=28, \mathrm{CO})$ and $\mathrm{m} / \mathrm{z}=$ 290.2 (splitting off of the side chain from the piperazinyl residue).

Two carbonyl groups were detected in the ${ }^{13} \mathrm{C}$ NMR spectrum at $\delta=202.4$ and $166.3 \mathrm{ppm}$, respectively. An intact piperazinyl moiety was established by the presence of the two $\mathrm{N}-\mathrm{CH}_{2}$-groups in the respective ${ }^{1} \mathrm{H}$ and ${ }^{13} \mathrm{C}$ NMR spectra, and the two OMe groups were detected at $\delta=56.3$ and $55.9 \mathrm{ppm}$, respectively; their unambiguous assignment was made by 2DNOESY NMR spectroscopy. The ${ }^{1} \mathrm{H}$ NMR spectrum also showed the presence of a $n$-propyl side chain. From these results as well as extra 2D NMR spectra, the structure of $\mathbf{2}$ was deduced as depicted in Fig 1.

A synthesis made independent confirmation of this proposal of $\mathbf{2}$ was designed and carried out (Scheme 1). Thus, commercially available 2-chloro6,7-dimethoxyquinazolin-4-amine (3) was allowed to react with piperazine ${ }^{20-24}$ for 6 hours at reflux temperature in water to yield $68 \%$ of known compound 4. The latter compound was transformed into target amide $\mathbf{2}$ by its reaction with 2-oxopentanoic acid in the presence of HOBT, EDCl and TEA to yield $50 \%$ of 2 . The sample obtained by synthesis was identical in each property (IR, UV-Vis, ${ }^{1} \mathrm{H}$ NMR, ${ }^{13} \mathrm{C}$ NMR, MS) with compound 2 obtained from the extraction of the drug.<smiles>COc1cc2nc(Cl)nc(N)c2cc1OC</smiles><smiles>[CH2-]C</smiles><smiles>CCC(=O)C(=O)N1CCN(c2nc(N)c3cc(OC)c(OC)cc3n2)CC1</smiles><smiles>COc1cc2nc(N3CCN(C)CC3)nc(N)c2cc1OC</smiles>

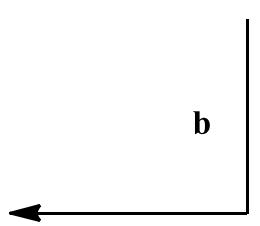

Scheme 1. Synthesis of compound 2: a) piperazine, water, $100^{\circ} \mathrm{C}, 6 \mathrm{~h}, 68 \%$; b) 2-oxopentanoic acid, DCM, $\mathrm{HOBT}, \mathrm{EDCl}, \mathrm{TEA}, 0^{\circ} \mathrm{C} \rightarrow 12 \mathrm{~h}, 25^{\circ} \mathrm{C}, 50 \%$

Terazosin $\mathbf{1}$ is synthesized from the reaction of $\mathbf{3}$ with $\mathbf{6}$ (Scheme 2) ${ }^{25}$; the latter compound can be obtained from the coupling of piperazine with 2-furoylchloride followed by hydrogenation in the presence of Raney nickel. Usually, hydrogenation of furans in the presence of metal catalysts leads to the formation of tetrahydrofurans in good yields.

However, there are some reports on ring-opening reactions under these conditions. Thus, 2-methylfuran forms 2-pentanone upon hydrogenation in the presence of $\mathrm{Ru}, \mathrm{Pt}, \mathrm{Pd}$ or a $\mathrm{ZnO} / \mathrm{Ni}^{26-32}$. Since these reactions usually give good yields when higher pressures and/or higher reaction temperatures are used, it can be assumed that - when applying low pressure of hydrogen and room temperature - this reaction only occurs as a minor side-reaction on a small scale. Thus, it seems highly probable that the impurity $\mathbf{2}$ observed in the end product is due to an already existing impurity 7 being formed during the synthesis of $\mathbf{6}$. Ring-opening reactions during the synthesis of $\mathbf{1}$ are known: For example, European 
Pharmacopoeia lists two impurities, a 5-hydroxypentanoyl compound (impurity F) and 2-hydroxy-pentanoyl compound (impurity J). The latter is related to the 2-oxo-penanoyl impurity $\mathbf{2}$ described here.

Terazosin, as well as the novel impurity $\mathbf{2}$ were tested for cytotoxic activity in sulforhodamine B assays ${ }^{33}$ employing several human tumor cells lines [A375 (melanoma), HT29 (colon carcinoma), MCF-7 (breast adenocarcinoma), A2780 (ovarian carcinoma), FaDu (hypopharynx carcinoma)] and non-malignant mouse fibroblasts (NIH 3T3). While 2 was not cytotoxic at all up to a concentration of $\mathrm{EC}_{50}=30 \mu \mathrm{M}$ (cut-off of the assay), terazosin ${ }^{34}$ was not cytotoxic for nonmalignant mouse fibroblasts (NIH 3T3 $\mathrm{EC}_{50}>30 \mu \mathrm{M}$ ) but slightly cytotoxic for HT29 $(22.4 \pm 1.6 \mu \mathrm{M})$, MCF$7(28.8 \pm 1.0 \mu \mathrm{M})$, A2780 $(20.1 \pm 0.7 \mu \mathrm{M})$, A375 $(26.6 \pm 1.7 \mu \mathrm{M})$ and $\mathrm{FaDu}$ cells $(3.1 \pm 1.3 \mu \mathrm{M})$, respectively.<smiles>COc1cc2nc(Cl)nc(N)c2cc1OC</smiles><smiles>C1CNCCN1</smiles>

piperazine<smiles>O=C(Cl)c1ccco1</smiles>

furoylchloride
$+$<smiles>CC1(C)CCCO1</smiles><smiles>COc1cc2nc(N3CCN(C(=O)C4CCCO4)CC3)nc(NI)c2cc1OC</smiles><smiles>O=C(c1ccco1)N1CCNCC1</smiles><smiles>CCCC(=O)C(=O)N1CCNCC1</smiles>

Scheme 2. Reported synthesis of terazosin $\mathbf{1}$ and the proposed mechanism for the formation of impurity 2

\section{Conclusion}

A hitherto unknown impurity in commercial samples of Terazosin was detected, isolated and its structure was elucidated by spectroscopy and independent synthesis. This contamination, 1-[4-(amino-6,7dimethoxyquinazolin-2-yl)-piperazin-1-yl]-pentane1,2-dione $\mathbf{2}$ is likely to occur as the product of a sidereaction in the catalytic hydrogenation step during the synthesis of the drug. Biological screening showed this compound as not cytotoxic for several human tumor cell lines and non-malignant mouse fibroblasts.

\section{Experimental}

\subsection{General}

Melting points are uncorrected (Leica hot stage microscope), NMR spectra were recorded using the Varian spectrometers Gemini 2000 or Unity 500 ( $\delta$ given in ppm, $J$ in $\mathrm{Hz}$ ), MS spectra were taken on a Finnigan MAT LCQ 7000 (electrospray, voltage $4.5 \mathrm{kV}$, sheath gas nitrogen) instrument. IR spectra were taken on a Perkin Elmer Spectrum Two (ATR) and UV/vis on a Perkin Elmer Lambda 14 instrument. TLC was performed on silica gel (Merck 5554); elemental analyses were performed on a Vario EL (CHNS). The solvents were dried according to usual procedures. For HPLC-DAD investigations a LaChrom D-7000 HPLC-system (from MerckHitachi) was used at an operating temperature of $25^{\circ} \mathrm{C}$ using RP-18 Superspher column
$(125-2 \mathrm{~mm}, 4 \mathrm{~mm})$ as the stationary phase.

\section{6,6-Dimethoxy-2-(piperazin-1-yl)-quinazolin-4- amine 4}

A mixture of 2-chloro-6,7-dimethoxyquinazolin-4amine $(3,9.96 \mathrm{~g}, 41.56 \mathrm{mmol})$ and piperazine $(35.8 \mathrm{~g}$, $41.56 \mathrm{mmol})$ in water $(50 \mathrm{~mL})$ was stirred at $100^{\circ} \mathrm{C}$ for $6 \mathrm{~h}$. After cooling to room temperature, an aqueous solution of $\mathrm{KOH}(0.85 \mathrm{~mol}, 50 \mathrm{~mL}, 1.7 \mathrm{~N})$ was slowly added, and the mixture was stirred for $1 \mathrm{~h}$ at room temperature (thereby the solution turned green, and a white precipitate was formed). The precipitate was filtered off, re-dissolved in water $(100 \mathrm{~mL})$ and extracted with a mixture of chloroform and isopropanol $(100 \mathrm{~mL}, 5: 1)$. The aqueous phase was extracted with a mixture of chloroform and isopropanol $(2 \times 100 \mathrm{~mL}, 5: 1)$, and the combined organic phases were washed with brine $(50 \mathrm{~mL})$. The solvents were removed under diminished pressure. The residue was recrystallized from methanol to yield $4(8.2 \mathrm{~g}, 68 \%)$ as a white solid; m.p. $223.8^{\circ} \mathrm{C}$ (from $\mathrm{MeOH})$ (lit. $\left.{ }^{24} 230-232^{\circ} \mathrm{C}\right) ; \mathrm{R}_{F} \quad\left(\mathrm{CHCl}_{3}: \mathrm{MeOH}\right.$ : $\left.\mathrm{NH}_{4} \mathrm{OH}, 90: 9: 1\right)=0.23$.

\section{1-[4-(Amino-6,7-dimethoxyquinazolin-2-yl)- piperazin-1-yl]-pentane-1,2-dione 2}

To an ice-cold solution of 2-oxopentanoic acid $(1.12 \mathrm{~g}, 9.6 \mathrm{mmol})$ in anhydrous DCM $(250 \mathrm{~mL})$, HOBT (1.51 g, $11.2 \mathrm{mmol}), \mathrm{EDCl}$ (3.68 g, 19.2 $\mathrm{mmol})$, and TEA (3.47 $\mathrm{mL}, 24.0 \mathrm{mmol})$ were very 
slowly added. After an additional stirring for $30 \mathrm{~min}$ at $25^{\circ} \mathrm{C}, 4(2.31 \mathrm{~g}, 28.8 \mathrm{mmol})$ was added, and the mixture was stirred for $12 \mathrm{~h}$ at room temperature. The precipitate was filtered off, and the filtrate was washed with saturated $\mathrm{NaHCO}_{3}$ solution $(2 \times 50 \mathrm{~mL})$, water $(2 \times 50 \mathrm{~mL})$ and brine $(2 \times 50 \mathrm{~mL})$. After drying $\left(\mathrm{MgSO}_{4}\right)$ and evaporation of the solvent under diminished pressure, the residual yellowish oil was purified by column chromatography $\left(\mathrm{CHCl}_{3} / \mathrm{MeOH} /\right.$ $\left.\mathrm{NH}_{4} \mathrm{OH}, 98: 1.8: 0.2\right)$ yielding $2(1.54 \mathrm{~g}, 50 \%)$ as an off-white solid; m.p. $175.4^{\circ} \mathrm{C} ; \mathrm{R}_{F}=0.21$;

IR (ATR): $v=2934 \mathrm{w}, 2876 \mathrm{w}, 2837 \mathrm{w}, 1709 \mathrm{~m}, 1622 \mathrm{~s}$, $1575 \mathrm{~m}, 1513 \mathrm{~m}, 1480 \mathrm{~s}, 1476 \mathrm{~s}, 1472 \mathrm{~s}, 1435 \mathrm{~s}, 1380 \mathrm{~m}$, $1239 \mathrm{~s}, 1208 \mathrm{~s}, 1174 \mathrm{~m}, 1130 \mathrm{w}, 997 \mathrm{~s}, 840 \mathrm{~m} \mathrm{~cm}^{-1}$; UV-Vis $(\mathrm{MeOH}): \lambda_{\max }(\log \varepsilon)=214$ (4.23), 250 (4.70), 275 (4.13), 324 (3.71) nm;

${ }^{1} \mathrm{H}$ NMR (400 MHz, DMSO- $\left.d_{6}\right): \delta=7.41(\mathrm{~s}, 1 \mathrm{H}, 3-$ $\mathrm{H}), 7.14\left(\mathrm{~s}, 2 \mathrm{H}, 7-\mathrm{NH}_{2}\right), 6.72(\mathrm{~s}, 1 \mathrm{H}, 6-\mathrm{H}), 3.81(\mathrm{~s}, 3 \mathrm{H}$, $\left.18-\mathrm{H}_{3}\right), 3.77\left(\mathrm{~s}, 3 \mathrm{H}, 19-\mathrm{H}_{3}\right), 3.77-3.70\left(\mathrm{~m}, 4 \mathrm{H}, 9-\mathrm{H}_{2}\right.$ $\left.+12-\mathrm{H}_{2}\right), 3.56-3.49\left(\mathrm{~m}, 2 \mathrm{H}, 10-\mathrm{H}_{2}\right), 3.39-3.32(\mathrm{~m}$, $\left.2 \mathrm{H}, 11-\mathrm{H}_{2}\right), 2.72\left(\mathrm{t}, J=7.2 \mathrm{~Hz}, 2 \mathrm{H}, 15-\mathrm{H}_{2}\right), 1.57$ $\left(\mathrm{h}, J=7.3 \mathrm{~Hz}, 2 \mathrm{H}, 16-\mathrm{H}_{2}\right), 0.90(\mathrm{t}, J=7.4 \mathrm{~Hz}, 3 \mathrm{H}, 17$ $\left.\mathrm{H}_{3}\right) \mathrm{ppm}$;

${ }^{13} \mathrm{C}$ NMR (101 MHz, DMSO- $\left.d_{6}\right): \delta=202.4(\mathrm{C}-14)$, 166.3 (C-13), 161.6 (C-7), 158.6 (C-8), 154.7 (C-2), 149.1 (C-5), 145.6 (C-1), 105.7 (C-6), 104.1 (C-3), 103.5 (C-4), 56.3 (C-19), 55.9 (C-18), 45.5 (C-11), 44.3 (C-12), 43.6 (C-9), 41.8 (C-15), 41.2 (C-10), 16.3 (C-16), 13.9 (C-17) ppm.

MS (ESI, $\mathrm{MeOH}$ ): calculated for $\mathrm{C}_{19} \mathrm{H}_{25} \mathrm{~N}_{5} \mathrm{O}_{4}: 387.19$, found: $\mathrm{m} / \mathrm{z}(\%)=388.27(100 \%$,

$[\mathrm{M}+\mathrm{H}]^{+}$; analysis calcd for $\mathrm{C}_{19} \mathrm{H}_{25} \mathrm{~N}_{5} \mathrm{O}_{4}$ (387.44): $\mathrm{C}$ 58.90, H 6.50, N 18.08; found: C 58.75, H 6.71, N 17.76; HRMS: calcd. 388.1979, found: 388.1977

\section{Acknowledgments}

We are grateful to Dr. A. Frolov (Leibniz-Institut für Pflanzenbiochemie Halle) for ESI-HRMS measurements and to B.Sc. V. Simon for the IR and UV-vis spectra. We kindly thank Dr. D. Ströhl and his team for many NMR spectra as well as the late Dr. R. Kluge for the ESI-MS spectra and his valuable assistance. Dr. S. Sommerwerk and M.Sc have performed preliminary studies. J. Wiese. Authentic Terazosin was donated by Chemische Fabrik Berg CFB, Bitterfeld-Wolfen. We like to thank Dr. Chr. Raschke (CFB) for helpful discussions.

\section{References}

1- S.B. Bari, P.S. Jain, A.A. Shirkhedkar, L.V. Sonawane, A.J. Mhaske, J.B. Gawad, Impurities in pharmaceuticals: a review, World J. Pharm. Res., 2015, 4, 2932-2947.

2- C.M. Callis, J.P. Bercu, K.M. DeVries, L.K. Dow, D.K. Robbins, D.L. Varie, Risk Assessment of Genotoxic Impurities in Marketed Compounds Administered over a Short-Term Duration: Applications to Oncology Products and Implications for Impurity Control Limits, Org. Process Res. Dev., 2010, 14, 986-992.
3- M. Honma, Thresholds of toxicological concern for genotoxic impurities in pharmaceuticals, in: F. Nohmi, S. Fukushima (Eds.) Thresholds of genotoxic carcinogens: From mechanisms to regulation, Academic Press, Amsterdam, 2016, 103-115.

4- S. Schmidtsdorff, A.H. Schmidt, Simultaneous detection of nitrosamines and other sartan-related impurities in active pharmaceutical ingredients by supercritical fluid chromatography, J. Pharm. Biomed. Anal., 2019, 174, 151-160.

5- M. Batty, R. Pugh, I. Rathinam, J. Simmonds, E. Walker, A. Forbes, S. Anoopkumar-Dukie, C.M. McDermott, B. Spencer, D. Christie, R. Chess-Williams, The role of $\alpha 1$-adrenoceptor antagonists in the treatment of prostate and other cancers, Int. J. Mol. Sci., 2016, 17, 1339.

6- M. Oelke, A. Gericke, M.C. Michel, Cardiovascular and ocular safety of $\alpha$ 1 -adrenoceptor antagonists in the treatment of male lower urinary tract symptoms, Expert Opin. Drug Saf., 2014, 13, 1187-1197.

7- A. Wadhawan, A. Banga, Y. Duan, M. Mennesson, Z.H. Wu, Alpha1-Adrenergic Receptor Antagonists Use in Treatment and Prevention of Psychiatric Disorders: A Review, Curr. Psychopharmacol., 2014, 3, 158-183.

8- H. Wood, Could a prostate drug be repurposed for Parkinson disease?, Nat. Rev. Neurol., 2019, 15,621 .

9- J.Q. Yuan, Y. Liu, Z.Y. Yang, X. Qin, K.H. Yang, C. Mao, The efficacy and safety of alpha1 blockers for benign prostatic hyperplasia: an overview of 15 systematic reviews, Curr. Med. Res. Opin., 2013, 29, 279-287.

10-U. Dunzendorfer, Clinical experience: symptomatic management of BPH with Terazosin, Urology, 1988, 32, 27-31.

11-H. Lepor, M. Baumann, E. Shapiro, The alphaadrenergic binding properties of Terazosin in the human prostate adenoma and canine brain, J. Urol. (Baltimore), 1988, 140, 664-667.

12-H. Lepor, D.I. Gup, M. Baumann, E. Shapiro, Laboratory assessment of terazosin and alpha-1 blockade in prostatic hyperplasia, Urology, 1988, 32, 21-26.

13-P.M. Parker, The 2019-2024 World Outlook for Pulmonary arterial hypertension (PAH) Therapeutics, Icon Group International, Las Vegas, 2018.

14-A.F. Fliri, W.T. Loging, R.A. Volkmann, Drug effects viewed from a signal transduction network perspective, J. Med. Chem., 2009, 52, 8038-8046.

15-A. Ghaleiha, K.M. Shahidi, S. Afzali, N. Matinnia, Effect of Terazosin on sweating in patients with major depressive disorder receiving sertraline: A randomized controlled trial, Int. J. Psychiatry Clin. Pract., 2013, 17, 44-47.

16-R. Mago, M.E. Thase, B.W. Rovner, Antidepressant-induced excessive sweating: 
clinical features and treatment with Terazosin, Ann Clin Psychiatry, 2013, 25, 186-192.

17-https.//www.parkinson-gesellschaft.de; last accessed 2020-01-22.

18-R. Cai, Y. Yuan, Z. Chen, Y. Han, X. Ji, R. Cai, Y. Li, W. Su, L. Gao, X. Ji, L. Liu, Y. Zhang, J.E. Simmering, J.L. Schultz, I. FernandezCarasa, A. Consiglio, A. Consiglio, A. Raya, A. Raya, P.M. Polgreen, N.S. Narayanan, C. Zhao, L. Liu, M.J. Welsh, Enhancing glycolysis attenuates Parkinson's disease progression in models and clinical databases, $\mathbf{J}$. Clin. Invest., 2019, 129, 4539-4549.

19- J. Xia, B. Feng, Q. Shao, Y. Yuan, W.X. Simon, N. Chen, S. Wu, Virtual screening against phosphoglycerate kinase 1 in quest of novel apoptosis inhibitors, Molecules, 2017, 22, 1029.

20-A. Cavalli, F. Lizzi, S. Bongarzone, R. Brun, R. Luise Krauth-Siegel, M.L. Bolognesi, Privileged structure-guided synthesis of quinazoline derivatives as inhibitors of trypanothione reductase, Bioorg. Med. Chem. Lett., 2009, 19, 3031-3035.

21-Z. Ma, Y. Lin, Y. Cheng, W. Wu, R. Cai, S. Chen, B. Shi, B. Han, X. Shi, Y. Zhou, L. Du, M. Li, Discovery of the First EnvironmentSensitive Near-Infrared (NIR) Fluorogenic Ligand for $\alpha 1$-Adrenergic Receptors Imaging in Vivo, J. Med. Chem., 2016, 59, 2151-2162.

22-Z. Ma, Z. Liu, T. Jiang, T. Zhang, H. Zhang, L. Du, M. Li, Discovery of Fluorescence Polarization Probe for the ELISA-Based Antagonist Screening of $\alpha 1$-Adrenergic Receptors, ACS Med. Chem. Lett., 2016, 7, 967-971.

23-A. Petty, N. Idippily, V. Bobba, W.J. Geldenhuys, B. Zhong, B. Su, B. Wang, Design and synthesis of small molecule agonists of EphA2 receptor, Eur. J. Med. Chem., 2018, 143, 1261-1276.

24-T. Sekiya, H. Hiranuma, S. Hata, S. Mizogami, M. Hanazuka, S. Yamada, Pyrimidine derivatives. 4. Synthesis and antihypertensive activity of 4-amino-2-(4-cinnamoylpiperazino)6,7-dimethoxyquinazoline derivatives, J. Med. Chem., 1983, 26, 411-416.
25-A. Bottini, S.K. De, B. Wu, C. Tang, G. Varani, M. Pellecchia, Targeting Influenza A Virus RNA Promoter, Chem. Biol. Drug Des., 2015, 86, 663-673.

26-N.S. Date, V. La Parola, C.V. Rode, M.L. Testa, Ti-doped Pd-Au catalysts for one-pot hydrogenation and ring-opening of furfural, Catalysts, 2018, 8, 252.

27-S. Mitsui, Y. Ishikawa, Y. Takeuchi, Hydrogenation end decomposition. 14. Part Catalytic reduction of the furan derivatives with Palladium-und Raney-Nickel-Katalysator, Chem. Zentralbl., 1965, 136, 16538.

28-I.F. Bel'skii, N.I. Shuikin, Catalytic hydrogenation and hydrogenolysis of furan compounds, Usp. Khim., 1963, 32, 707-736.

29-N.I. Shuikin, R.A. Karakhanov, I. Ibrakhimov, Conversion of tetrahydrofuran homologs over palladized carbon, Izv. Akad. Nauk SSSR Ser. Khim., 1965, 1, 165-167.

30-S. Wang, V. Vorotnikov, D.G. Vlachos, A DFT study of furan hydrogenation and ring-opening on Pd(111), Green Chem. 2014, 16, 736-747.

31-N.I. Shuikin, I.F. Bel'skii, Hydrogenation of furan compounds over nickel catalysts, $\mathrm{Zh}$. Obshch. Khim., 1959, 29, 3627-3631.

32-T. Mizugaki, T. Yamakawa, Y. Nagatsu, Z. Maeno, T. Mitsudome, K. Jitsukawa, K. Kaneda, Direct transformation of furfural to 1,2-pentanediol using a hydrotalcite-supported platinum nanoparticle catalyst, ACS Sustain. Chem. Engin., 2014, 2, 2243-2247.

33-M. Kahnt, J. Wiemann, L. Fischer, S. Sommerwerk, R. Csuk, Transformation of asiatic acid into a mitocanic, bimodal-acting rhodamine B conjugate of anomolar cytotoxicity, Eur. J. Med. Chem., 2018, 159, 143-148.

34-N. Kyprianou, C.M. Benning, Suppression of human prostate cancer cell growth by a 1-adrenoceptor antagonists doxazosin and Terazosin via induction of apoptosis, Cancer Res., 2000, 16, 4550-4555. 